\title{
Growth Factor Inhibition
}

National Cancer Institute

\section{Source}

National Cancer Institute. Growth Factor Inhibition. NCI Thesaurus. Code C40579.

Growth Factor Inhibition involves interference with, or restraint of, the activities of extracellular signaling molecules (ligands) involved in the control of target cell proliferation, survival, and differentiation. Inhibition may involve interference with growth factor binding to receptors. 